\title{
Surrogacy and the Motherhood Question in Yoruba Culture
}

\author{
Oyekan Adeolu Oluwaseyi ${ }^{1}$ and Ani Amara Esther ${ }^{2}$
}

1 \& 2. Department of Philosophy, Lagos State University, Ojo, Nigeria.

Email: adeoluoyekan@gmail.com and amaraesther35@gmail.com

\begin{abstract}
One of the arguments against surrogacy is that it is harmful to both the surrogate mother and the child. Numerous strands of this argument are collectively referred to as the 'harm factor'. A version of the argument says that surrogacy interrupts the Mother-fetal affection which develops between the surrogate mother and the child. If this is true, what implication does it have for the concept of motherhood? Does the biological connection between the fetus and the surrogate put the latter in a better position as a mother than the commissioning mother? This paper examines the relationship between surrogacy and motherhood within the context of Yoruba culture. It argues that the culture emphasizes the sociological dimension of motherhood more than the biological. This, the paper argues, is because of the culture's emphasis on the significance of nurture and care to the development of a meaningful and stable life. The paper thus concludes that while Yoruba traditional society lacked the scientific wherewithal to undertake a successful surrogacy procedure, its conception of motherhood, prevalently held even in contemporary time, is normatively compatible with surrogacy.
\end{abstract}

Key Words: Surrogacy, Motherhood, fetus, Yoruba, culture.

Introduction: The debate on the normative nature of surrogacy, for sometimes now, has been controversial. All manner of hyphenated versions of harm factor have been invoked to trash the hard nut of surrogacy. A strand, for instance, holds that surrogacy disrupts and undercuts the genetic-maternal affection existing between the surrogate and her child. If this is true, what implication does it have for the concept of motherhood? Does the biological connection between the fetus and the surrogate put the latter in a better position as a mother than the commissioning mother?

This paper views surrogacy through the prism of Yoruba culture, and asks questions such as: What is the Yoruba conception of surrogacy? Does this conception presuppose a Yoruba understanding of surrogacy? If it does, what is the contribution of this Yoruba understanding of surrogacy to the moral discourse? In a bid to answer these questions, the paper will first present the main ideas of surrogacy. Then, it will discuss the notion and nature of motherhood in Yoruba culture. And finally, while presenting the harm argument, the paper will also discuss the notion of surrogacy implicit in Yoruba traditional belief. It aims to establish that the Yoruba surrogacy is morally compatible with surrogacy.
Defining Surrogacy: Surrogacy is "a practice whereby a woman becomes pregnant with the intention of giving the child to someone else upon birth."i In a surrogacy arrangement, an agreement or understanding is entered between a woman (surrogate) and another person(s) (intending parents or commissioning couples). This memorandum of understanding includes: $(A)$ the consent of the woman (surrogate) to become pregnant, with the intention that-(i) a child born as a result of the pregnancy is to be treated as the child of the other person(s); and (ii) the woman will relinquish the custody and guardianship of the child born as a result of the pregnancy to the other person(s). (B) The consent of the other person(s) to become permanently responsible for the custody and guardianship of a child born as a result of the pregnancy.i

In the past, surrogacy arrangements were generally confined to kith and kin of close relatives, family, or friends, usually as an altruistic deed. In such a traditional surrogacy arrangement, the surrogate is the donor of the egg through a sexual intercourse with the male of the intending parents. Earliest examples are recorded in the bible. According to the bible, Sarah beseeched her husband to take in Hagar, her maidservant, in order to bear a child. The arrangement was successful but met a tragic end 
when Hagar refuses to relinquish the child, Ishmael.iii The bible also recorded Rachel giving her maidservant, Bilhah, to her husband, Jacob, as a surrogate because of her infertility. Bilhah bore two sons, Dan and Naphtali, for Joseph and Rachel. iv However, surrogacy assumed an entirely new face around 1976, with the success of artificial insemination. Under this procedure, the surrogate is either injected with the egg or the sperm or both, depending on the agreement. In such an arrangement, the surrogate has no genetic link to the child; and she is being paid to carry the baby to term. With the commercialization of surrogacy, the process has extended its network beyond family, community, state, and across the world.

Motherhood: A Yoruba Perspective: In order to have adequate understanding of the whole idea of surrogacy among the Yoruba people, it is imperative to briefly discuss their beliefs about motherhood. Yoruba people, found in South-West of Nigeria, occupies the whole of Ogun, Ondo, Oyo, Ekiti, Lagos and some part of Kwara State. ${ }^{\vee}$ A fraction of Yoruba people can also be found in Republic of Benin, Dahomey, Togo and Côte d'lvoire. Yet, quite a number of Yoruba cultural practices are preserved in some parts of the Carribean and South America, particularly in Cuba and Brazil, as well as in North America. ${ }^{\text {vi }}$

In Yoruba culture, motherhood is considered critical to family and lineage survival. vii It must be said that in traditional Yoruba society, where orality was the means of preservation, proverbs are the means of documenting ideas. A Yoruba proverb says;

lya ni wura iyebiye

(Mother is a precious gold)

Ti a ko le fowora

(That cannot be purchased with

money)

O poyun mi f'osu mesan

(She carried me in her womb for nine

months)

O pon mi f'odun meta

(She nursed me for nine months)

lya ni wura iyebiye

(Mother is a precious gold)

Ti a ko le f' owora

(That cannot be purchased with money). ${ }^{\text {viii }}$
This symbolism of motherhood with gold shows loveliness, attractiveness, prettiness, gorgeousness, magnificence and fineness. Every file and rank in the society wants gold, they want to be associated with gold because of the joy, praise, respect and happiness it brings. That is how motherhood is celebrated in Yoruba culture. Just like owners of gold are considered rich and very important in the society, in the same vein mothers are revered and celebrated in Yoruba culture. This can be well epitomized with these traditional Yoruba adages; "Iya ni wura, baba ni jigi" (mother is gold and father is a mirror). ${ }^{\text {ix }}$

Now, motherhood being concomitant with gold shows that traditional Yoruba culture considers motherhood to be among the highly ranked on the ladder of social importance. Some Yoruba proverbs that throw more light on this point are; "omo k'oni ohun o ye, iya ni ko gba (a child survives and thrives only at the mother's will),"x "Orisa bi iya ko si, ta ni o je se omolomo lo re? (There is no supporting divinity greater than one's mother; who dares be a benefactor of another person's child)."xi This shows that the continuous existence of a child lies in her palms. She guides, leads and directs the affairs of the child towards a certain goal. Also, Ifa corpus succinctly explains this as follows:

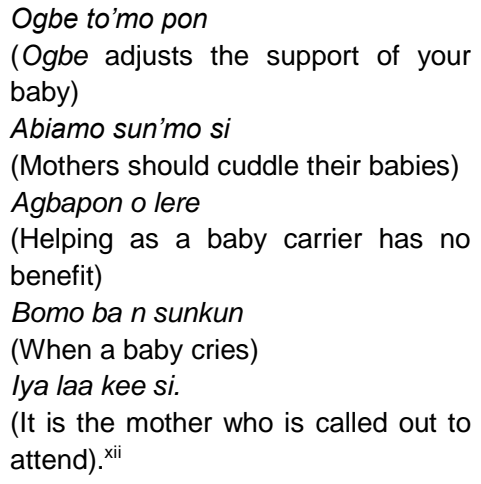

The above excerpt from Ifa corpus explains the importance and the role of a mother. As a mother, she has the responsibility of cuddling, caring, nurturing, singing and playing with her child. She also has the responsibility of teaching her morals. If her child turns bad, the mother is held responsible. Yoruba do say that a bad child is a carbon copy of her mother (omo buruku ni ti iya). 
Primarily, what bestows motherhood to a wife is her ability to bear children or as Oladele Balogun puts it, being a "mother is tied to child birth."According to traditional Yoruba songs;

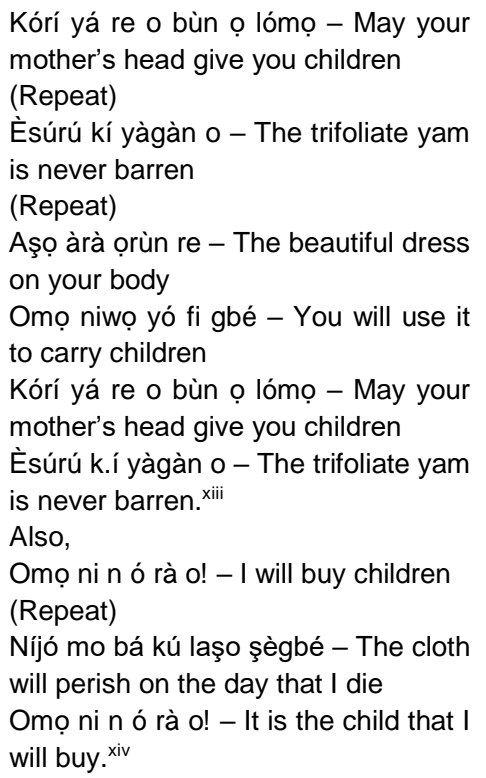

In the first song, a prayer is made on behalf of the bride that she will bear children like her mother did. This is because, in marriage, children are sources of joy. The second song tells us how important childbearing is to a wife that she will give up the best things of life for it.

In Yoruba culture, children largely determine the relations between one generation and the next; children are replacement; they will one day stand in their parents place. This unilineal and partrilineal descent system can be well captured with this proverb; "Olomo lo loko" and, "bi ina baku, afi eru boju bi ogede ba ku afi omo re ropo" (when fire is put out, it is survived by ashes, when banana plant dies, it replaces itself with its sweater). Thus, children sustain the patriarchal kinship system: "Omo ni ere aiye; omo eni nii jogun eni ni ojo ti a ba ku" (Children are the gains of this world; it is one's children that inherits one at death). ${ }^{\mathrm{xv}}$

Thus, it becomes a challenge for a woman not to have children. As captured in this song; "Omo l'okun, omo n'ide, Enia t'o wa saye ti ko bimo, Aye asan lo wa" which literally means "child is a coral bead; a child is silver, A person who has none has not lived a fulfilled life."xvi When a woman bears no child, she is left dejected, and seriously troubled. This challenging situation makes her feel like an incomplete woman because she has failed in bringing a child into the marriage. She is metaphorically naked, and has no child to cover her nakedness. A Yoruba proverb says; "omo eni laso eni" (one's child is ones cloth).

In Yoruba traditional society, an infertile couple is believed to have chosen a bad orí (destiny). According to Yoruba creation mythology, after emi (the active element of life) has been put in ara, the newly created human being proceeds to the house of Ajala for the choice of orí. It is the orí that one chose that determines his or her personality. xvii Hence, when a couple is met with the bad fate of infertility, the ori is faulted since it is regarded as "an individual's personal destiny that caters for their personal interest."xviii As explained in this traditional Yoruba song:

Emi o mo ibi ol'ori yan ori o (I do not know where people with good destiny chose their destiny).

Mba lo yan temi (I would have gone to choose mine there).

Ibi kannaa l'ati yan ori o (But no! we chose our destiny from the same source).

Kadara ko papo ni. (It's only that our destinies are not identical). ${ }^{\text {xix }}$

In addition however, witchcraft, evil spirits, Juju, curse by ancestors or deities, aran ginisa (womb worm) have been identified as various secondary causes of infertility by the Yoruba. ${ }^{x x}$ In order to remedy infertility, sacrifices are made to Oludumare through the Ifa priest that appeals on behalf of the bearer of a bad destiny. Through this process, a couple may be asked to give alms to beggars with babies or care and cater for an orphaned child; or in some cases the husband is asked to take in a second wife. The essence, of this as Gbadegesin has noted, is to bring blessings of childbirth into the family. Also, the couples will be given herbal medicines to ingest in order to stop infertility.

But in cases where these interventions fail, couples are regarded as parents through the care and nurture of other children. This is because Yoruba people 
believe that a child does not belong only to the mother but, also, to the whole community. In this light, every member of the society can be a parent to the child next door. This sociological conception of parenting includes those without children into the family of parenthood. It then entails that genetic link or biological link is necessary but not sufficient in capturing the totality of motherhood in Yoruba culture. Hence, motherhood inculcates caring, nurturing and responsibility. Yorubas will say;"Obi'ni ko lo lomo bi kose on' woni.(Child ownership resides not only in biological motherhood but also in child mothering)." When a couple is caring for a neighbor's child or an orphan, the child refers to them as his/her parents. In essence, motherhood goes beyond the gamut of genetic link to the realm of care and nurture in Yoruba culture.

Surrogacy, Harm and Motherhood: One of the most frequently expressed worries with respect to surrogate motherhood is that it harms both the child and the surrogate mother. This is captured in Matthew Tieu's argument, for instance, that;

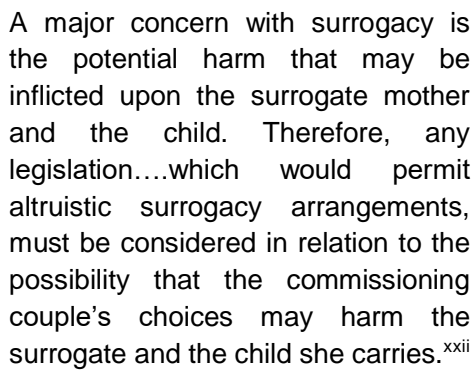

This means in effect that "the link created through gestation and birth is "more weighty" than the genetic link between the fetus and the commissioning parents."xxiii The reason adduced is that during pregnancy, the placenta, which controls the transfer of hormones from mother to the fetus, bonds mother and child. This hormonal transfer from mother to the child adds a uniquely different size, proportions, development, cell differentiation, and congenital normality or abnormalityxxiv to the child's biological makeup. This argument seems to be faring well with the recent discovery of epigenetics and microchimerism which shows that "postgestational michrochimerism, the existence of foetal cells in the mother (child---mother) or of mother cells in the child (mother-child) after pregnancy, is real. "Child-mother migration is more abundant than mother-child, and foetal cells are found in the mother's body several decades after giving birth." $x \times v$ However, surrogacy makes little or nothing of this bond by introducing another mother, the commissioning mother. In the words of Tieu; "surrogacy ruptures this bond, and such is the importance of the emotional attachment between the surrogate mother and the child she has carried..."xxvi

A problem with Tieu's argument is the over-emphasis on genetic link as a determinant factor in motherhood. $\mathrm{He}$ assumed that the essence of a human being is the gene which acts as a determinant of who we are. That is why he wrote that we "ought to be especially concerned with any process that disrupts the important bond between mother and child, which derives from both biological and cognitive/psychological aspects of human nature, beginning during gestation and continuing after birth." But this need not be the only determinant of motherhood. While we do not deny the importance of a child's link to his gestational mother, we are saying that motherhood embodies other things, among which is the intent to be a mother.

The intent to be a mother prepares the intended mother to be ready for the seen or unseen consequences of her moral decision. This intent carries the responsibility to cater for the child's social and moral well being. As John L. Hill avers; "biological parents are considered legal parents in our culture not because of their biological relationship with their children, but because of what the biological relationship evidences-namely, the intention to raise the child, the means to bring the child into existence, and the ability to care for the child after birth. Where couples lack the physical capacity to bear a child but possess the more fundamental indicia of parenthood, their status as parents should be recognized and honored even above those who claim a biological relationship with the child."xxvii

Thus, contrary to Tieu, we hold that gestational link is not morally significant in terms of surrogate motherhood, and does not constitute a sound argument against it. 
It has also been argued that surrogate motherhood, with its attendant separation of the surrogate mother from the baby, causes suffering to the child. Two scenarios have been painted to capture the suffering the child undergoes under surrogate motherhood. On the first hand, a child that has been successfully handed over to the intended parent might develop a feeling of maternal abandonment. On the second hand, the fate of a deformed child is unjustly decided within surrogacy arrangements. Surrogacy arrangement makes it a burden to the surrogate to decide the fate of a deformed fetus. In cases where abortion is ruled out, the surrogate mother is left with the responsibility of nurturing and caring for a deformed child, a task for which she is not psychologically ready. In such a state of affairs, the child might not be well taken care of and might possibly grow up with the belief that he is not wanted because of his deformity. In these circumstances, the child is vulnerable to "(...) depression, anxiety, various physical symptoms of psychological distress, feelings of insecurity or suicidal tendencies."xxviii

Besides, Marcus Johanson Agafors argues that fetuses are not blank states. ${ }^{\text {xxix }}$ They are aware and responsive to the environment outside the womb; which means that they begin to develop attachments prenatally. Truncating the developing attachment by handing the baby over to the commissioning parents therefore amounts to harming the child, "since such attachment is crucial to successfully developing social and emotional functioning." $\times x x$ The point being made, though quite unsuccessful in our view, is that surrogacy creates an identity problem for the baby, mainly as a result of the transfer from the surrogate mother to the commissioning parents. We believe that while the fetus may be sensationally aware of its environment, there is nothing to show that such awareness informs the sort of consciousness salient to the formation of an identity. In other words, there is no possibility of interpreting and associating meanings to the change in the environment by the fetus. It is perhaps for this reason that, as Agafors himself conceded, empirical evidence suggests that surrogate babies do relatively well when observed years later. It is one thing to prove that fetuses and babies are aware of changes around them, it is yet another thing to prove that such changes constitute harm, especially at the long run. The changes to which they grow accustomed as fetuses and newly born infants are cumulatively less significant to their long term stability as individuals, compared to the environment of nurture. Biological bonds tend to fade as people grow and form relationships that are more psychologically and sociologically cogent.

Surrogacy and Yoruba Culture: The question at this point is whether Yoruba culture is compatible with surrogate motherhood. Segun Gbadegesin provides an insightful answer to this question. In his works, Bioethics and Culture and Bioethics and an African System, Gbadegesin made a claim that surrogacy is compatible with Yoruba culture. He argues that Yoruba culture accommodates things that promote the common good of the people and jettisons those that negate the communal wellbeing. ${ }^{x \times x i}$ This pragmatic aspect of Yoruba culture makes it amenable with surrogacy. He mentions two scenarios where surrogacy practice is evident in Yoruba culture. The first is when a "husband is advised, sometimes by the first wife, to marry a younger woman in the hope that the spirit of the child so born into the family, will attract a child for the first wife too." xxxii Again, an infertile woman "arranges for her husband to marry another woman of her choice on the understanding that she will carry the first wife's child." $x x x i i i$

However, Gbadegesin's argument is somewhat problematic. The weight he placed on Yoruba appropriation of a second wife has, in fact, no significance to surrogacy in the sense in which it is widely conceptualized. If a husband marries another woman in order to bear a child, both of them are the parents of the child. The second wife does not relinquish the child to the husband and the first wife, and neither is she paid for her service. Besides, the first wife only becomes a step mother to the child in question. This being the case, what Gbadegesin parades as surrogate motherhood in Yoruba culture is actually obtaining a second wife, due to inability of the first wife to bear a child, in order to keep the family tree alive. Consequentially, Gbadegesin implicitly denies what he is trying to affirm and affirms what he is trying to deny: surrogacy is incompatible with Yoruba culture. Moreover, it is not in all cases that the appropriation of a second wife brings a child to the 
home. And Gbadegesin failed to tell us what happens in such a situation. Does the husband appropriate more wives? If yes, what if the appropriation of more wives yields no result? Or does he resign to fate and be condemned to childlessness in the biological sense?

Fayemi and Akintunde have also argued that "surrogacy and adoption as presented by Gbadegesin in traditional Yoruba culture presupposes so many complications if it is adopted in contemporary times. This is because the rationale behind these issues in traditional setting cannot hold water in contemporary times." "xxiv They supported this with the instance that Gbadegesin's argument ruled out a greater possibility of the surrogate requesting for her child or failing to fulfill her surrogacy contract as obtainable in modern surrogacy. Thus, according to them, to refine Yoruba surrogacy method in the furnace of modern surrogacy method will be highly detrimental.

Given the failure of Gbadegesin to demonstrate how compatible Yoruba culture is with surrogacy, how then are we to proceed? The link, in our view, lies in the normatively superior consideration accorded to the sociological dimension of motherhood. As we have shown, considerable effort is invested into biological procreation. But when such efforts fail, the one who is not able to bear a child is not considered barren in the social sense. There is a Yoruba proverb that says; "eni bimo, omo lo maa sin, eni ti o bimo, omo lo maa sin." it means that he who has children will be buried at death by children. He who doesn't have children will equally be buried by children at death. The idea is that even if such persons are biologically barren, they are sociologically fruitful through the nurture and care of other children. This social parenthood is anchored on the belief that motherhood transcends the genetic bond (between the mother and the child) to responsibility, care and nurture. So an infertile couple who takes the responsibility of feeding, clothing, sheltering and moral building of orphans is regarded as a parent. Surrogacy in this sense is therefore more normative than descriptive.

On a last note, it is important to examine the problem of the bastard, illegitimate child in Yoruba culture, even if in passing. The legitimacy of a child is paramount to marriage stability in Yoruba culture. As a result, every family wants to prove that a child is their direct offspring. It thus becomes abominable for a family to go out of wedlock to have children. ${ }^{x x v}$ It must be stated that there exists a clear difference between an illegitimate child, often a product of a secretive liaison between a wife and another man; and a surrogate child, genetically related to the commissioning parents, and brought to life, though a third party, but out of mutual consent nonetheless. The surrogate child can therefore not be rightly described as an illegitimate child. It then implies that in contemporary times, surrogacy can be an addition to the hitherto limited pathways to parenthood. Those who contract a third party to carry a baby for them are still socially legitimate parents, for as long as they discharge the responsibility expected of them to the child, irrespective of the manner of conception.

Conclusion: Thus far we have been able to establish that in Yoruba culture, having a child is considered critical to family and lineage survival. While in the traditional society there was no technology to make surrogacy possible, great efforts are made to overcome challenges relating to fertility, including propitiation, or the acceptance of a second wife in the hope that the arrival of children through such means will pave way for the first wife. But when these fail, the couples make recourse to caring and catering for other children who awards them the medal of parenthood. Society regards as a mother, a woman who though unable to conceive, has nonetheless demonstrated the capacity to nurture and raise children. While expectations of procreation by an interested community of friends and relatives put a challenged couple under pressure and undue attention, such a situation is countervailed by the eventual acceptance of such a woman into the class of mothers, in spite of the biological limitations, upon the manifestation of the requisite sociological qualities. To address the challenge of infertility in contemporary time, surrogacy, within a culture which has a normatively sociological conception of motherhood offers promises that are quite enormous. This way, the gap between the biological and sociological demands of motherhood becomes further bridged, through the scientific procedure of surrogacy. 


\section{Competing Interests: None}

Author Contribution: $1^{\text {st }}$ author conceived the idea, outlined the literature review and edited the manuscript. $2^{\text {nd }}$ author guided to develop the manuscript and check same meticulously.

\section{References}

1. Mengual, A. \& Wolfie, N. Surrogacy.White Paper,2015; p.2.

2. Surrogacy Act 2010.

3. KJV, Genesis, 16 vs. 3-6.

4. KJV, Genesis, 30 vs. 1-2.

5. Balogun, A. The Concept of Ori and Human Destiny in Traditional Yoruba Thought: A Soft Deterministic Approach. Nordic Journal of African Studies,2007; 16 (1): 166-130.

6. Lawal, B. The Gelled Spectacle: Art, Gender, and Social Harmony in an African Culture. Washington: University of Washington Press 1996 p. xiv

7. Makinde, T. Motherhood as a Source of Empowerment of Women in Yoruba culture. Nordic Journal of African Studies, 2004; 13 ( 2 ) : $164-174$.

8. Balogun, A. O. Authentic Motherhood: Traditional YorubaAfrican Perspective. International Journal of Philosophy, 2012; 41 (2):3.

9. Op. Cit, Makinde, 2004 p.165.

10. Ajibola, J. Owe Yoruba. Ibadan: Oxford University Press.1977 p.23.

11. Op. C.t, Balogun 2012 p.4.

12. Salami, A. Ifa a Complete Divination. Lagos: NIDD

Publishing and Printing limited 2002 p.36.

13. Op. Cit, Balogun 2012 p.3.

14. Ajibade, G. O. Is there no Man with Penis in this land? Eroticism and Performance in Yoruba Nuptial Songs. African Study Monographs, 20005; 26 ( 2 ) : 99-113.

15. Op. Cit, Ajibola 1977 p.30.

16. Op. Cit, Makinde 2004 p.167.

17. Gbadegesin, S. "ENIYAN: the Yoruba Concept of a

Person" in P. H. Coetzee \& A. P. J. Roux (eds.), The African Philosophy Reader. New York: Routledge. 1998 p.155.

18. Abimbola, W. The Yoruba Concept of Human

personality. La notion de Personneen Afrique Noire

Colloques Internationale de Centre National de la

Recherche Scientifique, 1971; (544): 69-85.

19. Op. Cit, Gbadegesin 1998 p.162.

20. Koster-Oyekan, W. Infertility among Yoruba Women:

Perceptions on Causes, Treatments and Consequences.

www. A jolly. Info/inde.php/ajrh/.../3831. Retrieved on 3/

$11 / 2016$.

21Op. Cit, Balogun 2012 p.3.

22. Tieu, M. Oh Baby Baby: The Problem with Surrogacy. In: Bioethics Research Notes, 2007; 17 (1):2

23. Reame, N. E. The Surrogate as a High-Risk Obstetric Patient. WHI, 1991; 1(3):151-154.

24. Rothman, B. K. "Reproductive Technologies off Hope and Serious Risks." In David Bender \& Bruno Leone (eds.), Biomedical Ethics: Opposing Views. U.S.A.: Greenhaven Press, INC. 1994 p. 50.
25. de La Hougue, C. \& Roux, C. Surrogate Motherhood and Human Rights Analysis of Human, Legal and Ethical Issues. Surrogate September, 2015; Issue 1: 10.

26. Op. Cit, Tieu 2007 p.2.

27. Hill, J. L. The Case for Enforcement of the Surrogate Contract. Politics and the Life Sciences, 1990; 8(2):147-60. 28. COMECE. "Opinion of the Reflection Group on Bioethics on Gestational Surrogacy: The Question of European and International Rules." http://www.comece.eu. Retrieved on 10/12/2016

29. Agnafors, M. The harm argument against surrogacy revisited: two versions not to forget. Medicine, Health care and Philosophy, (2014); 3(17): 357-363.

30. Ibid p.9.

31. Gbadegesin, S. Bioethics and culture. In Helga, $\mathrm{K}$ and Singer, P. (eds.), A companion to Bioethics. Maiden: Blackwell publishing Itd. 2009 p.13.

32. Op. Cit, Gbadegesin 1993 p.260.

33. Ibid p.260.

34. Fayemi, A. K. \& Akintunde, F. A. On The Myth Called

'African Bioethics': Further Reflections on Segun

Gbadegesin's Account. Bangladesh Journal of Bioethic; 2012; 3(3):4-11.

35. Jegede, A. S. \& Fayemiwo, A. S. (2010). Cultural and Ethical Challenges of Assisted Reproductive Technologies in the Management of Infertility among the Yoruba of Southwestern Nigeria. African Journal of Reproductive Health, 2012;14(2):121. 
Bangladesh Journal of Bioethics 2017; 8(3):26-32

(2) 